\title{
Management Strategies for Sustainable Forest Biodiversity Conservation in Protected Areas of Bangladesh: A Study of Bhawal National Park, Gazipur
}

\author{
Md. Alauddin ${ }^{1}$, Md. Nuralam Hossain*2,1, Md. Babul Islam³, Shahidul Islam, ${ }^{4}$, Md. Kamrul Islam6 \\ ${ }^{1}$ Department of Environmental Science and Resource Management, Mawlana Bhashani Science and \\ Technology University, Tangail-1902, Bangladesh \\ ${ }^{2}$ School of Environment and Ecology, Chongqing University, Chongqing 400045, China \\ ${ }^{3}$ Koyra Government Mohila College, Koyra, Khulna-9290, Bangladesh \\ ${ }^{4}$ Chongqing Engineering Research Center for Remote Sensing Big Data Application, School of \\ Geographical Sciences, Southwest University, Chongqing 400715, China \\ ${ }^{5}$ Department of Geography \& Environmental Studies, University of Chittagong, Chattogram 4331, Bangladesh \\ ${ }^{6}$ USAID's Nature and Life Project, Community Development Center (CODEC), Teknaf, Cox's Bazar, Bangladesh \\ *Corresponding author (E-mail: nuralam_esrm@yahoo.com) | ORCID: 0000-0003-0029-9367
}

How to cite this paper: Alauddin, M., Hossain, M.N., Islam, M.B., Islam, S. and Islam, M.K. (2020). Management Strategies for Sustainable Forest Biodiversity Conservation in Protected Areas of Bangladesh: A Study of Bhawal National Park, Gazipur. Grassroots Journal of Natural Resources, 3(3): 56-72. Doi: https://doi.org/10.33002/nr2581.6853.03035

Received: 27 June 2020

Reviewed: 21 July 2020

Provisionally Accepted: 30 July 2020

Revised: 20 August 2020

Finally Accepted: 31 August 2020

Published: 15 September 2020

Copyright (C) 2020 by author(s)

This work is licensed under the Creative Commons Attribution International License (CC BY 4.0). http://creativecommons.org/licenses/by/4.0/

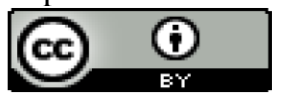

Open Access

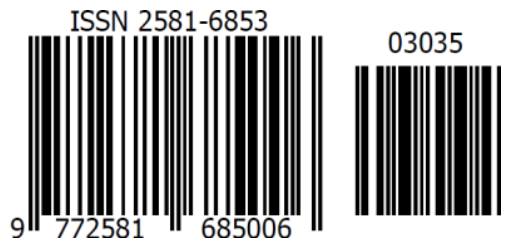

\begin{abstract}
Bhawal National Park (BNP) is one of the biologically historic and rich habitats in Bangladesh. Therefore, the study aimed to assess the current management strategies of BNP for sustainable biodiversity conservation along with investigations focusing underlying causes of deforestation and biodiversity losses. A structured questionnaire survey, interview, focused group discussions (FGDs), key informant interviews (KII), and literature survey were used as research tools. The results reveal some threats to the sustainable park management, such as its proximity to urban areas, encroachment, abundance of private land within its boundaries, and the pressure of rapid industrialization. It is found that extensive fuelwood collection, industrial setup, agricultural activities, forest fire, forest land encroachment, wood collection are significant causes for deforestation and biodiversity loss. Moreover, number of species of plants and wildlife has decreased roughly by one-third and one-half, respectively. The findings of this study are valuable for sustainable forest biodiversity conservation and management apart from formulating relevant strategies, planning, and policies for the protected areas of Bangladesh.
\end{abstract}

\section{Keywords}

Biodiversity loss, Deforestation, Management strategies, Protected area, Bhawal National Park (BNP) 
Doi: https://doi.org/10.33002/nr2581.6853.03035

\section{Introduction}

Protected areas (PAs) are one of the most promising and effective biodiversity conservation strategies and forest resources management sites (Masum et al., 2015). Globally, there has been a significant increase of PAs over the last few decades in recognizing importance for the protection of biodiversity. Today, there are more than 100,000 PAs in the world, covering approximately $12 \%$ of the world's land surface (Ahsan, Aziz and Morshed, 2016). However, the effective management and enforcement of rules and regulations are not abided during the establishment of PAs (Rashid, Craig and Mukul, 2016). Thus, various drivers of global change, such as population pressure, climate change, and land-use change pattern have affected these high conservation value areas, and the global biodiversity situation is threatened more than ever in the history (FAO, 2006; Akber and Shrestha, 2013).

Bangladesh, the world's largest deltaic region, lies in the Northeastern part of South Asia, between $20^{\circ} 34^{\prime}$ and $26^{\circ} 38^{\prime} \mathrm{N}$ latitude and $88^{\circ} 01^{\prime}$ and $92^{\circ} 41^{\prime}$ E longitude (Mukul, 2007; Hossain, Rahman and Islam, 2016; Salehin et al., 2020). The majority of the country's land is formed by rivers alluvium adjoining the Ganges and Brahmaputra and their tributaries (Sohel et al., 2015; Makul, Biswas and Rashid, 2018), which consists of some hilly areas (12\%), flood plains (80\%) having subtropical monsoon weather (Islam, 2003; Hossain et al., 2019; Ghosh et al., 2020). Moreover, Bangladesh is the part of the Indo-Burma biodiversity hotspot, which is one of the 10 globally significant areas with high species biodiversity (Nishat et al., 2002; Islam and Ma, 2018). For its unique geophysical location, Bangladesh is exceptionally characterized by a rich biological diversity (Nishat et al., 2002; Chowdhury and Koike, 2010). An estimated 5,700 species of angiosperms (Mukul, 2007; Rahman and Vacik, 2015), of which about 221 species of plants, have been recorded in BNP (Kabir and Ahmed, 2005). According to BFD, the country has 2.5 million ha of forestland (hill forest, Sal forest and tidal mangrove forest), equivalent to $17.4 \%$ of country's total area, out of which 1.6 million ha area is managed by the BFD (BFD, 2016; Islam, Jashimuddin and Hossain, 2017; Rahman and Miah, 2017). Although there are inconsistencies about the total area of forest land, but the National Forest Assessment 2007 reported about 1.44 million ha which is about 9.8\% of the total land (MoEF and FAO, 2007). However, FAO's Global Forest Resources Assessment 2015 reported that total forest area of Bangladesh is 1.43 million ha i.e., $11.2 \%$ of the land. The per capita forest land in Bangladesh is less than 0.015 hectare and 19 million people are directly dependent on forest resources for their survival (FAO, 2015). The forestry sector contributes for about 3\% of the country's GDP and $2 \%$ of the labour force (Rahman and Miah, 2017). Thus, Bangladesh has been facing a critical situation for the country's biodiversity conservation and ecosystem services for the last decades.

The status of the biodiversity of Bangladesh has deteriorated day by day, mainly due to its high population pressure and extreme poverty (Mukul et al., 2008; DoE, 2015). For the protection of the biodiversity and natural resources of all types of ecosystem, 34 protected areas covering 327,876 hectares have been established so far as per the provisions of the Bangladesh Wildlife Conservation Order 1973 (Chowdhury, 2014; Rahman and Vacik, 2015). The majority of the PAs of the country is being declared very recently (Mukul and Quazi, 2007). Bangladesh has four categories of PAs, including national parks (NPs), wildlife sanctuaries, eco-parks, and game reserves that have been defined under the Bangladesh Wildlife Preservation Act, 1974. Presently, there are 34 declared protected areas in Bangladesh surrounding all types of ecosystem (Chowdhury, 2014). Among those, 17 are national parks (NPs) in total 45,746 ha, 17 are wildlife 
sanctuaries in total 270,479 ha and only 1 is a game reserve with a total area of 11,651 ha (BFD 2013; Chowdhury, 2014; Rahman and Vacik, 2015). Covering almost 2\% of the country's total area, the protected areas of Bangladesh cover $11 \%$ of the total forest area, an average of $5 \%$ of the hill forests, $11 \%$ of the Sal forests and 23\% of the mangrove forests being protected (Mukul 2007; Chowdhury, Koike and Muhammed, 2009).

Bhawal National Park (BNP) is one of the historic and rich habitats in Bangladesh. It has a significant influence on environmental, social and economic balance, but the biodiversity of this forest is now under threat due to some underlying causes (Hasan and Khalid, 2014). The BNP has some unique characteristics compared to other PAs in terms of proximity to urban areas, the abundance of private lands and pressures of rapid economic development projects (Chowdhury, 2013; Hasan and Khalid, 2014). Besides, a diverse group of the local population is living in and around the park, who are migrated from the countryside and urban areas and have settled in the buffer zone (Chowdhury, 2013). In addition, there are various ethnic communities, such as the Kuch, who live within the boundaries of the park (Chowdhury, 2013). In BNP, the majority of agricultural land inside the park is owned by the Forest Department giving no right to people to manage private land (Hasan and Khalid, 2014; Macura, Secco and Pullin, 2015). Another pressure on the BNP is that there are over 150 industries in and around the buffer zone, with thousands of workers from these industries living around the park (NSP, 2006; Chowdhury, 2013; Masum et al., 2015). Fuelwood collection, significant activity in BNP, is another practice that threats forest biodiversity (Chowdhury, 2013; Hasan and Khalid, 2014). Ground fires are a common feature in BNP that destroy vegetation, medicinal herbs and shrubs. Thus, approximately $70 \%$ of forest habitats have been damaged as a result of these factors in the last 4-5 decades (Chowdhury, 2013).

The BNP is divided into two zones: a core area and buffer zone area. Activities like the establishment of industries, extraction of forest resources, and the planting of exotic species are prohibited at the core zone (GOB, 2006; Mohd et al., 2008). However, all of the activities are allowed in the buffer zone where only the park beat is nominated as the core zone, and the rest of the beat is located in the buffer zone (Mohd et al., 2008; Chowdhury, 2013). There are two categories of forest ranges in BNP: National Park Range and Bhawal Range. The National Park Range consists of three beats, such as Park, Bankharia and Baupara, while the Bhawal range consists of four beats namely Bhabanipur, Rajendrapur West, Baroipara, and Bishawakuribari (Masum et al., 2015). As a result, conflicts arise between officials and the local population on land use, particularly for the ownership of disputed land (Sharma et al., 2006; Chowdhury, 2013). Further, the Forest Department is planting the fast-growing timber species of short rotation to increase forest biomass, which is called exotic monocultures (Sharma et al., 2006; Hasan and Khalid, 2014). This reforestation activity has threatened the biodiversity of the park immensely. In addition, the residents and ethnic people of the BNP harvest plants and fruits for their consumption from the park. Sometimes, they also hunt jungle fowl and wild boar for household consumption, which is a significant threat to forest biodiversity loss (Sharma et al., 2006; Jahan et al., 2017). Therefore, this study is aimed to investigate the existing park management techniques of Bhawal National Park (BNP), identify the underlying causes of deforestation and degradation of forest biodiversity. 
Doi: https://doi.org/10.33002/nr2581.6853.03035

\section{Materials and Methods}

\section{Location and description of the study area}

Geographically, Bhawal National Park (BNP) lies between the latitudes $24^{\circ} 02^{\prime}$ to $24^{\circ} 11^{\prime} \mathrm{N}$ and longitude $90^{\circ} 21^{\prime}$ to $90^{\circ} 28^{\prime} \mathrm{E}$ (Figure 1) in Gazipur district under the Forest Division of Dhaka, about $40 \mathrm{~km}$ north of the capital city Dhaka, from where it is easily accessible throughout the year by road (Kabir and Ahmed, 2005). It has been marked under IUCN Management Category IV as a protected landscape. The protected area was established and maintained as a national park since 1974, while it was declared officially in 1982 under Bangladesh Wildlife Act, 1974. This NP covers 5,022 hectares area including 950 ha core area, which is managed by the Bangladesh Forest Department (Jahan et $a l ., 2017)$. The current feature of the forest area is honeycombed with habitations and rice fields. The topography is characterized by low hills, which rise from 3.0 to 4.5 meters above the surrounding rice fields, known locally as "Chalas", which are crossed by several depressions or baids (Kabir and Ahmed, 2005; Masum et al., 2015). The dominant Sal trees (Shorea robusta) have been removed almost. In contrast, a large number of exotic trees species have been planted as part of the conservation program, covering 90\% of the area (Sarker and Fazlul Huq, 1985). Recently, 221 species of plants ( 24 species of climbers, 27 species of grasses, 3 species of palms, 105 species of herbs, 19 species of shrubs, and 43 species of trees) have been recorded (Kabir and Ahmed, 2005). The NP is a safe habitat for many mammals such as Bengal fox (Vulpes bengalensis), jackal (Canis aureus), small Indian civet (Viverricula indica), wild boar (Sus scrofa), etc. The avifauna is similar to that found in Madhupur National Park (Kabir and Ahmed, 2005; Hossain et al., 2015).

\section{Sampling design}

Administratively, BNP comprises two forest ranges namely Bhawal Forest Range and National Park Range. The present study was carried out in two villages namely Bhabanipur and Baroipara, situated in Bhawal Forest Range of BNP Sal forest. These two villages were selected purposively because of abundance of industrial setup, land encroachment, new settlements, densely populated areas, and over-extraction of forest resources, which ultimately cause degradation and depletion of forest biodiversity. Total 90 survey questionnaires were completed in the study area. The respondents were selected randomly from various forest stakeholders for the questionnaire survey and interviews. In order to fulfill the study objectives, the different forest stakeholder groups (workers, day labourers, farmers, ethnic people, and businessmen) were selected purposively. The demographic characteristic of the respondents was 67\% male and 33\% female. Most of the respondents $(54 \%)$ were in the age group of $30-40$ years. $47 \%$ of the respondents came from nonresidential areas, $37 \%$ from streets and migrated area. A relatively higher percentage $(50 \%)$ of the respondents was illiterate. It was identified that among the respondents, $40 \%$ were day labourers, $34 \%$ were farmers, and $17 \%$ were service persons. $44 \%$ of the respondents' monthly income was $3000-5000$ BDT, whereas the income of $34 \%$ was $5000-8000$ BDT.

\section{Data Collection methods and analysis}

Both primary and secondary data were used for this study. The primary data were gathered from various forest stakeholders through observations, questionnaire surveys, key informant interviews (KII), and focus group discussion (FGD). The structured questionnaire survey was conducted in this study, which is considered as a useful tool that can provide in-depth and detailed information 
regarding the objective of the study. The questionnaire used both open and closed-ended questions. However, it was more common to use open-ended questions to obtain in-depth information about the causes of deforestation and biodiversity loss.

Interviews were conducted with multiple classes of respondents, including day labourers, visitors, local farmers, workers, local ethnic community, and forest resource collectors for understanding the exact causes of deforestation and biodiversity loss in BNP. However, three KIIs were conducted with the personnel of the Forest Department (FD) (i.e., Beat Office, Range Office, Divisional Forest Office) and local community leaders. Furthermore, two FGD sessions were carried out with local farmers, workers, resource collectors, and people in business, where a total of 18 respondents actively participated. In the FGD sessions some key questions were asked based on the study objectives such as forest dependency, causes of biodiversity loss and deforestation, existing management systems exercised by the FD. Apart from primary data, the collection of secondary data was based on existing literature, books and reports. Moreover, the existing park management facilities, the status of biodiversity, and constrains of park management data were collected from Forest Range Office and Divisional Forest Office of the BNP and the Ministry of Environment, Forest, and Climate Change. The collected data was edited and coded in a database for further analysis. The data analysis was carried out by Statistical Package for the Social Sciences (SPSS) version 22, and MS Excel-2007.

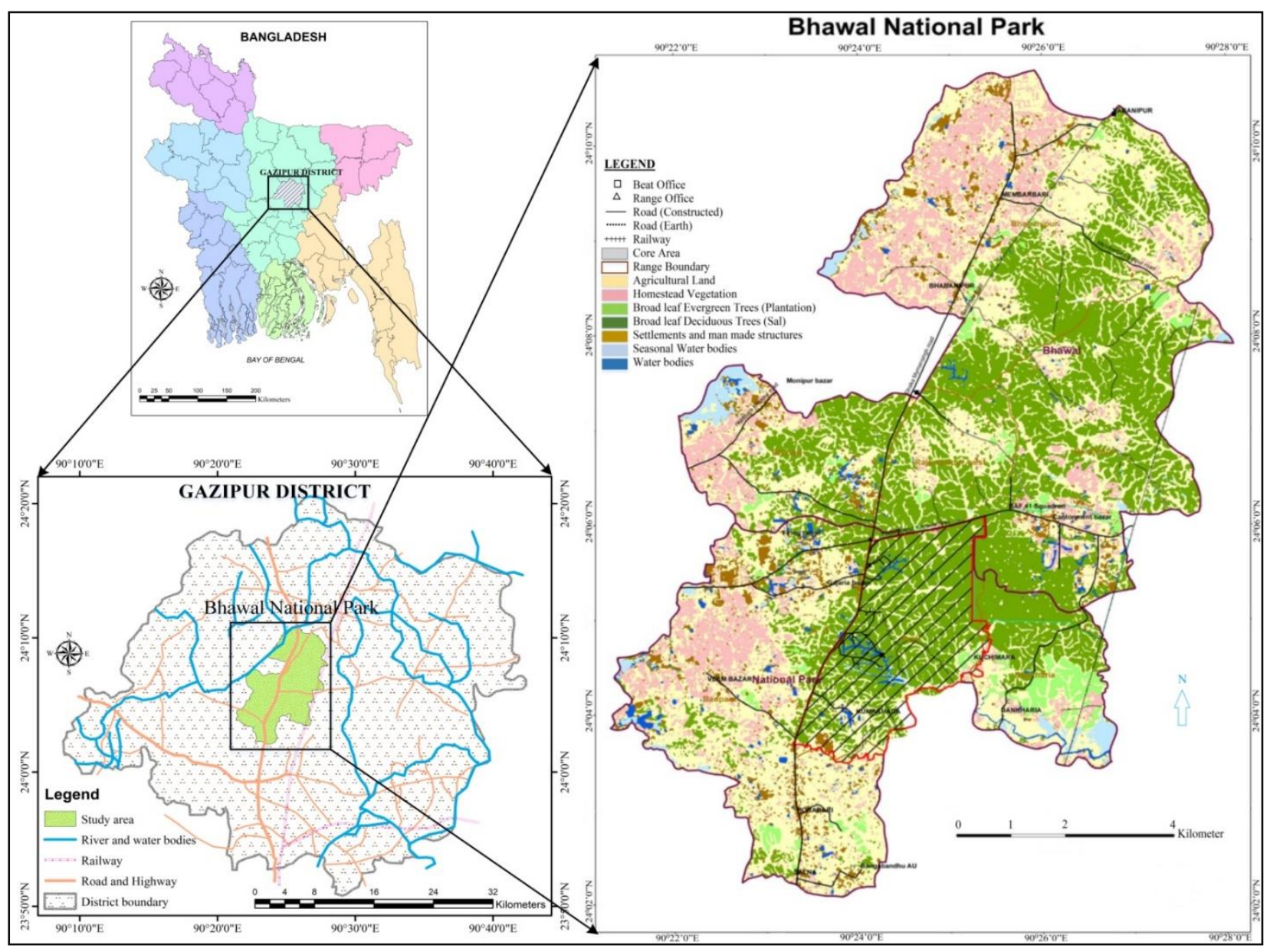

Figure 1: Location of the study area Bhawal National Park in Bangladesh 
Doi: https://doi.org/10.33002/nr2581.6853.03035

\section{Results and Discussion}

\section{Structural management and major hindrances to park development in Bhawal National Park}

The vicinity to town areas, forest land encroached, the abundance of private lands within its boundaries, and pressures of rapid industrialization are certain features of BNP that make it a unique PA. Most of the national parks in Bangladesh are situated away from the urban areas, while BNP is the only park that is close to the capital city of Bangladesh. BNP has a limited number of facilities for park management, such as mini zoo, a wildlife breeding centre, and a child park, which are not sufficient for better park management. Other facilities, such as the number of picnic spots, cottages and watchtower are not also enough to support existing number of visitors (Table 1).

Table 1: Existing park management facilities of BNP

\begin{tabular}{cc}
\hline Facilities Provided by $F D$ & Number \\
\hline Rest house & 6 \\
VIP rest house & 4 \\
Non-VIP rest house & 2 \\
Cottage & 13 \\
Picnic spot & 5 \\
Ponds & 50 \\
Watchtower & 2 \\
Child park & 1 \\
Mini zoo & 1 \\
Wildlife breeding centre & 1 \\
\hline
\end{tabular}

Source: BFD (2016)

In winter, a large number of visitors come to BNP mainly for picnics and nature observation. The Bangladesh government earns significant revenue from the park. For example, in 2011, the park earned BDT 15,150,000 (equivalent to USD 214,000) from about 10,000,000 visitors. Visitors walking in the park often disturb wildlife as they are not restricted to footpaths and designated areas (Rahman and Vacik, 2009). The human resources who are responsible for management (Table 2) are not sufficient and are not well trained to contribute to better park management. Therefore, the existing Sal forest management practices are inadequate and inefficient to sustainable management of the forest.

\section{Drawbacks with present management strategies}

The trees that are planted by the Bhawal National Park are grown and nurtured in Rajendrapur range.It means that the Assistant Conservator of Forest (ACF) has dual responsibility that could lead to conflicts in future regarding administration of the trees (Kabir and Ahmed, 2005). BNP is not a 100\% reserve forest (RF) because there are still 52 families residing in 400 acres of the forest land that have yet to give their land to the Forest Department. The Sal forest has been managed under two working ranges: (a) National Park Range, and (b) Bhawal Range. The National Park Range consists of three beats, such as Park, Bankharia, and Baupara, while the Bhawal Range consists of four beats, namely Bhabanipur, Rajendrapur West, Baroipara, and Bishawakuribari (Rahman and Vacik, 2009). For management purposes, BNP is divided into two zones: a core zone 
and a buffer zone. However, all kinds of economic activities are prohibited, such as establishing a business, harvesting all types of forest products, and planting exotic species. Besides, only park beat is designated as the core zone, and the rest of the beats are in the buffer zone. In contrast, neither a survey nor any census was carried out to count mammals and reptiles. As previous studies also reported, the Sal forest management policies cannot be successfully implemented due to the following main causes: densely populated areas, livelihoods dependency on forests, firewood collection for wage earning, conflicts between local and political elites, and encroachment of forest land by locals (Rahman et al., 2010). Corruption at various tiers of management systems, illicit removal of forest timber and poaching of wildlife are some of the major constraints in successful implementation of development projects (Alam et al., 2008; Rahman et al., 2010).The antagonistic relationship between the Forest Department and locals is an obstacle for effective Sal forest management (Alam et al., 2008).

Table 2: Existing human resources and order of BNP for park management

\begin{tabular}{cc}
\hline Person responsible park management & Numbers \\
\hline Chief Conservator of Forest & 1 \\
Deputy Chief Conservator of Forest & 4 \\
Conservator of Forest & 8 \\
Divisional Forest Officer & 1 \\
Assistant Conservator of Forest & 1 \\
Range Officer & 2 \\
Forester & 5 \\
Deputy Ranger & 2 \\
Forest Guard & 14 \\
\hline Total & 38 \\
\hline
\end{tabular}

Source: BFD (2016)

The factor responsible for deforestation and degradation of forest biodiversity

Daily Fuelwood Collection

Comprehensive fuelwood collection, a significant activity in BNP, is a threat to forest biodiversity. This activity continues throughout the years, while the collection is more intense during the dry season. Fuelwood is usually collected for both domestic consumption and commercial sale. It is observed that majority of the collectors are adults, both male and female, and adolescent boys. The fuelwood collectors are mostly poor, and they supplement their income by selling fuelwood. As displayed in Figure 2, 46\% of the respondents opined that 35-40kg fuelwood is collected daily for household cooking purposes. Further, $29 \%$ of people opined that $30-35 \mathrm{~kg}$ firewood is collected daily to earn income, followed by $17 \%$ responding that $40-45 \mathrm{~kg}$ fuelwood for commercial sale and $8 \%$ of them saying that $15-20 \mathrm{~kg}$ is being collected for Forest Department staff. Similar research findings revealed that an average $11-15 \mathrm{~kg}$ of fuelwood is collected daily for household consumption in Modhupur National Park (MNP) (Hossain et al., 2015; Hasan et al., 2020). 


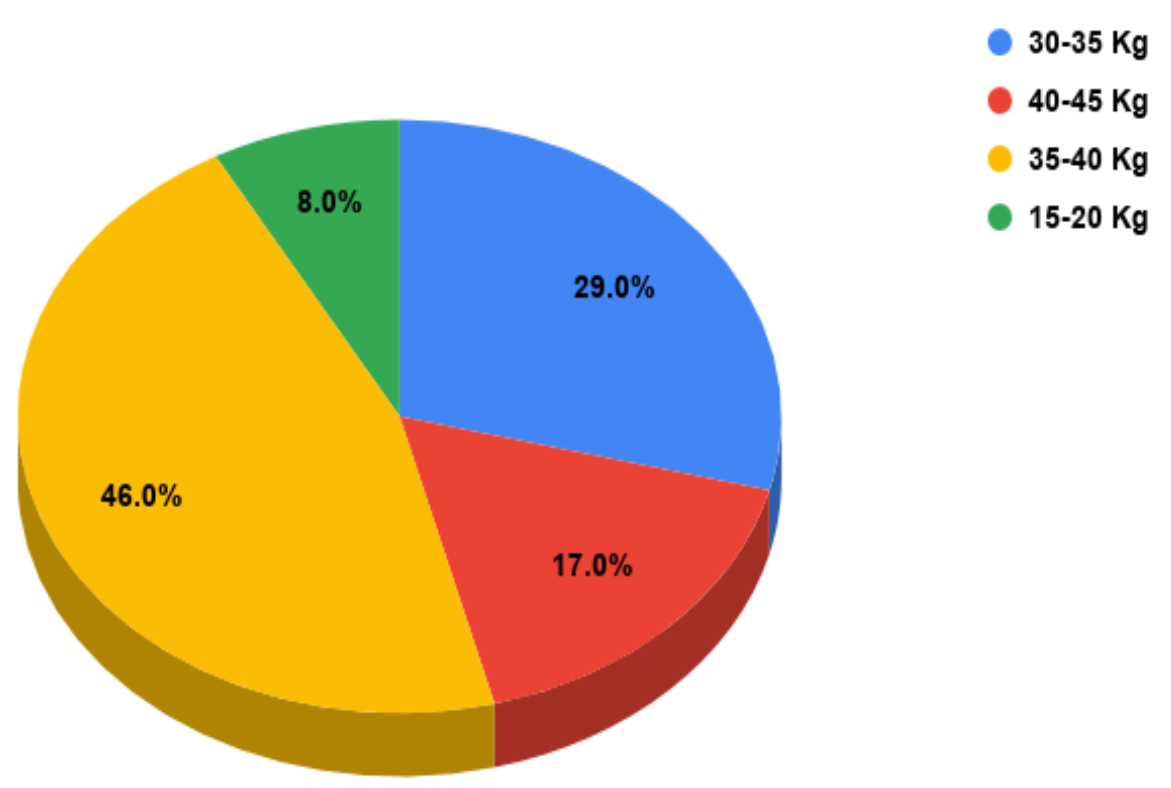

Figure 2: Daily fuelwood collection for various purposes

\section{Types of Industries}

There were found many small, medium and heavy industries surroundings the park as well as inside the park. It is unique NP in Bangladesh having industries inside the core area of the park, where the denim and spinning mills are operating for a long time. Findings indicated that more than 150 industries were actively working in the buffer zone and the areas immediately surrounding the park (Masum et al., 2015). Therefore, not only pollutants (water, air, soil and sound) of the industries but also thousands of workers from these industries are residing in the buffer zone area, creating immense disturbance to biodiversity conservation. It is revealed that the industrial setups in the study area mostly included textiles (knitting, dyeing and garments), ceramics, chemicals, poultry feeds, plastics, shoe factories, poly bags, gum, medicines and other small and medium industries. Overall, $65 \%$ of industrial setup was of textile industries, and about $17 \%$ of them were poultry feed producing industries (Figure 3). However, not only industrial pressure, but also consequently, settlements and infrastructural developments such as grocery stores, auto repair garages, and hair cutting salons have played a detrimental role in the diminishing of Sal forests.

\section{Agricultural Activities}

Traditionally, the agricultural activities practiced by farmers inside of the BNP for decades and are considered one of the major causes of deforestation and loss of forest biodiversity. This study identified various diversifications of agricultural activities that are practiced inside the forest land, like cash crops, corn-producing activities, and some other activities. The findings are depicted in Figure. $4.60 \%$ of the respondents opined that corn-producing activities are generally practiced by local people inside the forest land, followed by $30 \%$ of cash crops and $10 \%$ of other activities. 
Previous studies have reported that the agricultural activities cash crops and corn producing for Modhupur National Park (MNP) are 21\% and 62\%, respectively (Hossain et al., 2015; Hasan et al., 2020).

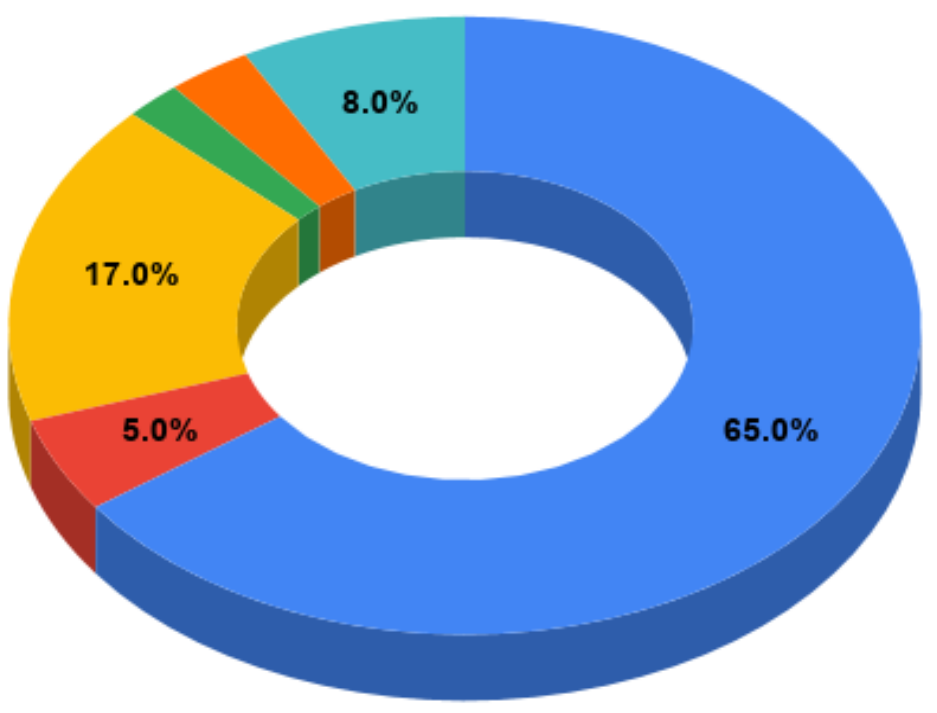

\section{Textile dying} industries

Chemical industries

Poultry feed industries

Pharmaceutical industries

Ceramics industries

Other industries

Figure 3: Types of industries in the buffer zone of Bhawal National Park

\section{Cash crop activities corn producing activites Other activities}

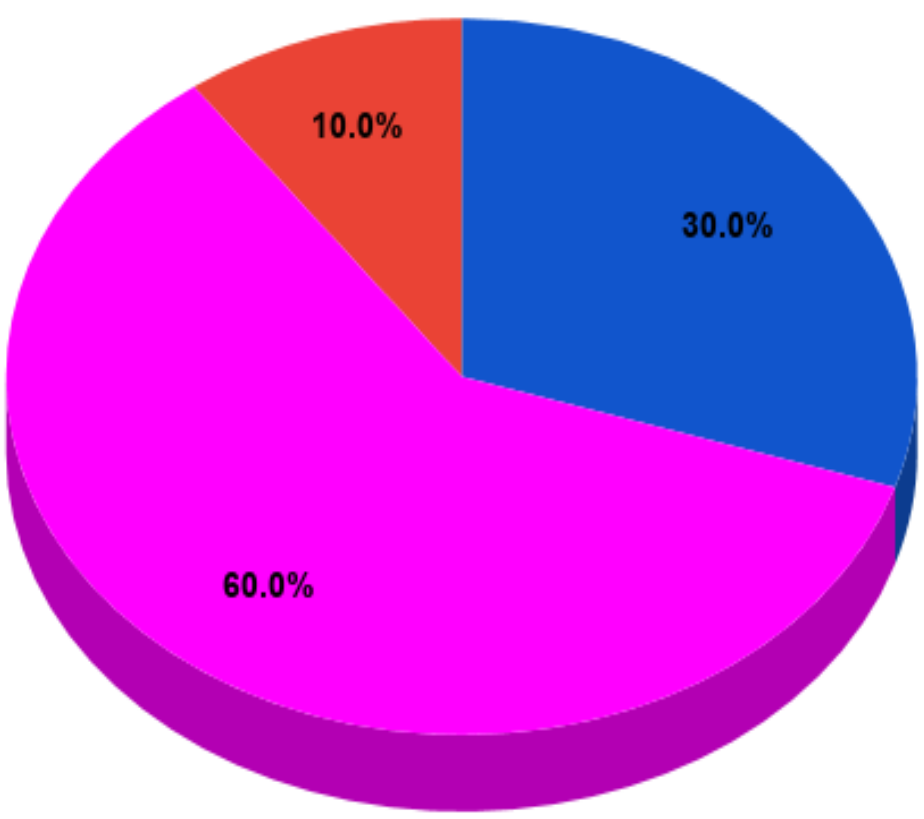

Figure 4: Agricultural activities inside of the BNP 


\section{Forest Fire}

Forest fire is an utmost cause for degradation and depletion of forest resources (Hossain et al., 2015). A forest fire may occur from natural and anthropogenic sources (Rahman and Vacik, 2009). Typically, at Sal forest, fire may occur in dry (summer) season by the friction of dry leaves of trees on the ground. Besides, when the fire source, such as an open flame, smoking, and electric sparks, or other sources of ignition, comes into contact of combustibles, a fire occurs. Present study revealed that $60 \%$ of respondents believed that BNP's wildfire has happened due to natural activities (Figure 5). Moreover, smoking by cigarettes or bidi may be a severe anthropogenic cause of forest fire, which accounts for $17 \%$. Similarly, $16 \%$ respondents opined that forest fire appears owing to people's carelessness, while $7 \%$ of respondents admit that forest fire happed by prohibited activities of the local inhabitant. In contrast, in the MNP, forest fires are caused by smoking (67\%), and $21 \%$ by illegal human activities (Hossain et al., 2015).

100

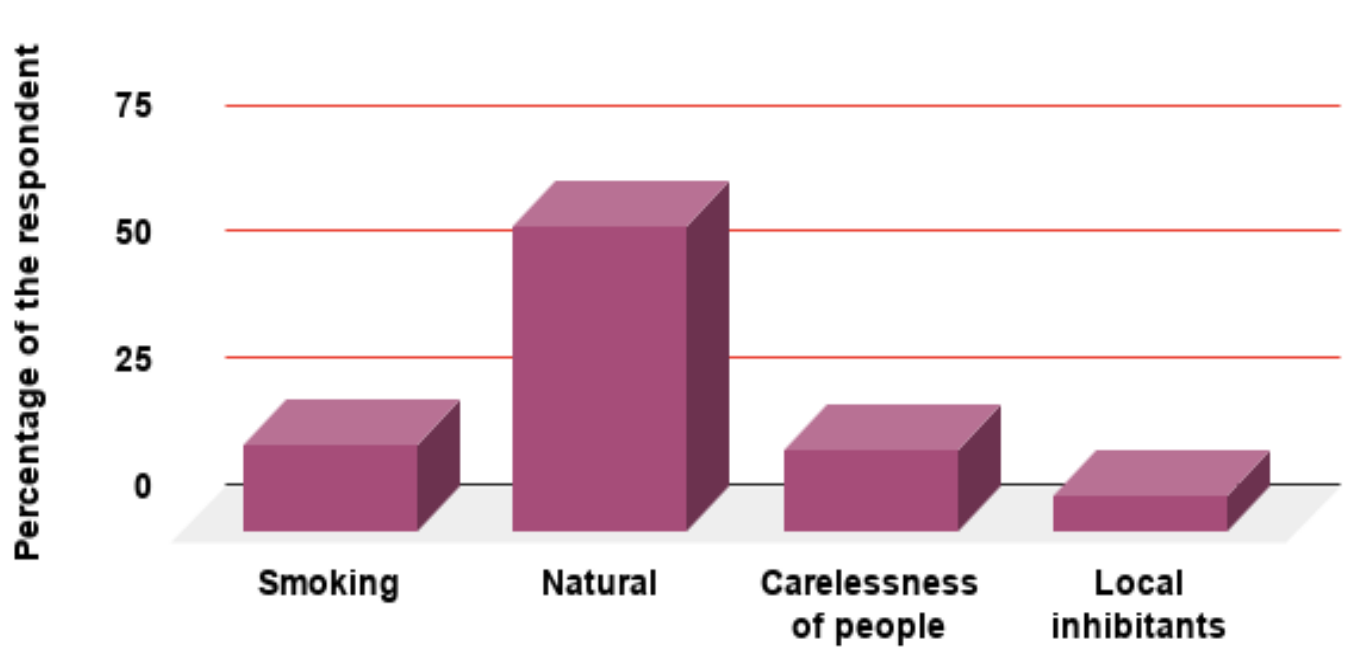

Causes of Forest fire

Figure 5: Causes of forest fire in BNP

Forest Land Encroachment

Forest land encroachment is one of the key reasons for forest habitat degradation (Hossain et al., 2015: Islam et al., 2017). This is due to the expansion of farmland, the development of new settlements, and the setup of industries such as clothing manufacturers, spinning mills and dyestuffs, pharmaceuticals, and poultry feed industries (Chowdhury, 2013). Almost 70\% of the forest habitat has been destroyed due to such practices over the last few decades (Rahman, Nishat and Vacik, 2009). As shown in Figure 6, 57\% of respondents in the study area assumed that forest land has encroached by the establishment of new industries around the BNP, followed by $27 \%$ by the development of new settlements and $16 \%$ by the expansion of agricultural lands. Sunderland et al. (2011) have found encroachment of forest land is the major forest conservation problems. The 
Sal forests are under constant anthropogenic pressure from all sides as there were no boundaries or demarcations off the forest. The areas under encroachments are estimated at 0.036 million ha, and the number of encroachers is about 100,000 .

100

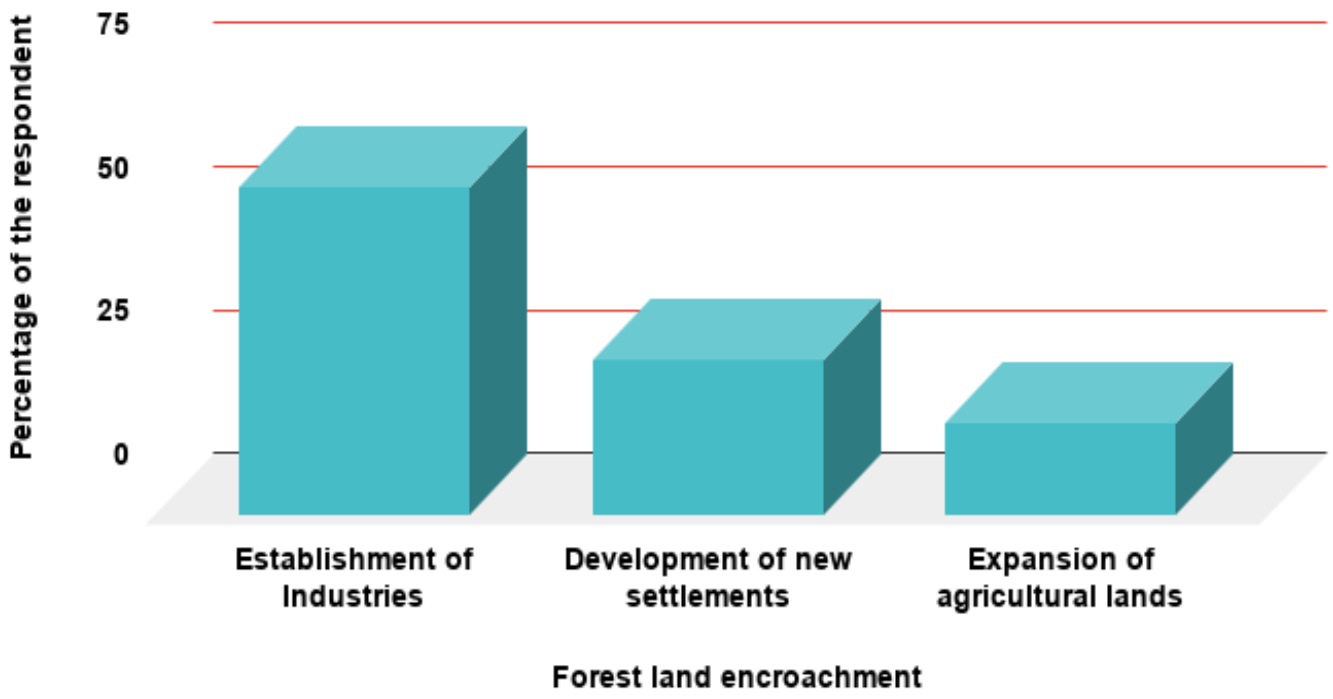

Figure 6: Causes of forest land encroachment in BNP

\section{Timber Felling}

It was found that timber forest products are used for various purposes of development activities. As presented in Figure 7, about 50\% of respondents opined that the timber forest products are directly going to saw mill around the forest to make furniture and other household ornamental products. In contrast, 34\% of respondents assumed that wood is getting sold to the brickfield for burning bricks, and $16 \%$ respondents revealed that trees are logged illegally by some local people. The result of this study is similar to the previous study conducted by Hossain et al. (2015) for MNP, in which timber forest products were used by saw mill (54\%) and brickfield (29\%). Another study by Sunderland et al. (2011) indicated that illicit removal of timber forest products from the forest is the major forest conservation barrier, which is responsible for depletion and degradation of forest biodiversity. Besides, the main causes of timber logging are wide gap between the demand and supply of wood and its consequent high prices, and unemployment in rural areas increasing the dependency on wood collection from forest.

\section{Forest biodiversity status}

\section{Floral Diversity}

It is found that the Sal forest is rapidly disappearing due to illegal logging, lack of proper management system of clear-felling, and forest encroachment by industries (Sunderland et al., 
2011). Consequently, the biodiversity of the forest is shrinking at an alarming rate. This study revealed that the number of tree species in BNP is 22, followed by grass (12), shrub (10) and climbers (6). Further, the study has found that the number of herb species existing in BNP is 5. The number of tree, shrub and grass species have declined by roughly one-third compared to the species that studies recorded in 1973 (Ismail and Mia, 1973) and half compared to the studies of 2009 (Rahman, Nishat and Vacik, 2009). Over the last few decades, this practice has destroyed about $70 \%$ of the forest habitat. Because of recent military activities, ground fires are destroying flora, kill medicinal herbs and shrubs as well, although they are still disappearing by human intervention and present practice (Chowdhury, 2013).

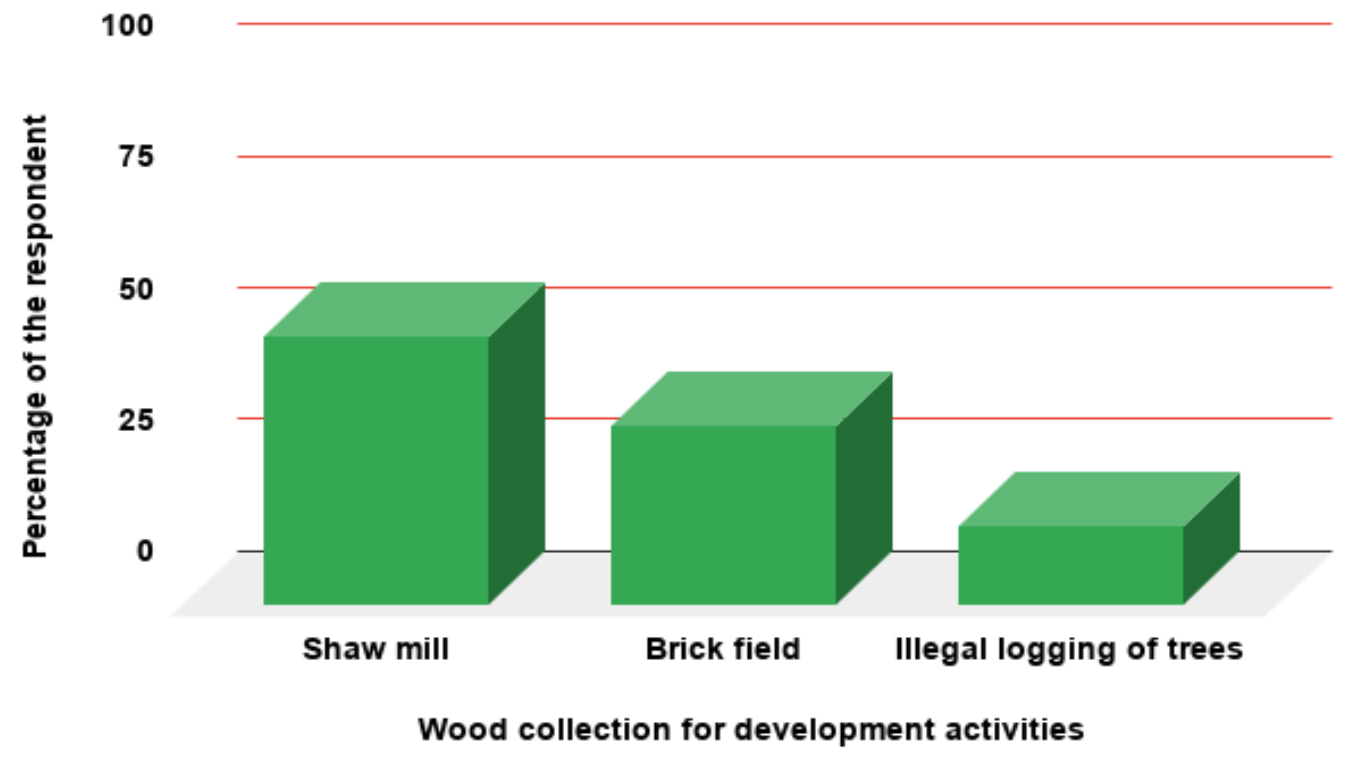

Figure 7: Wood collection for development purposes

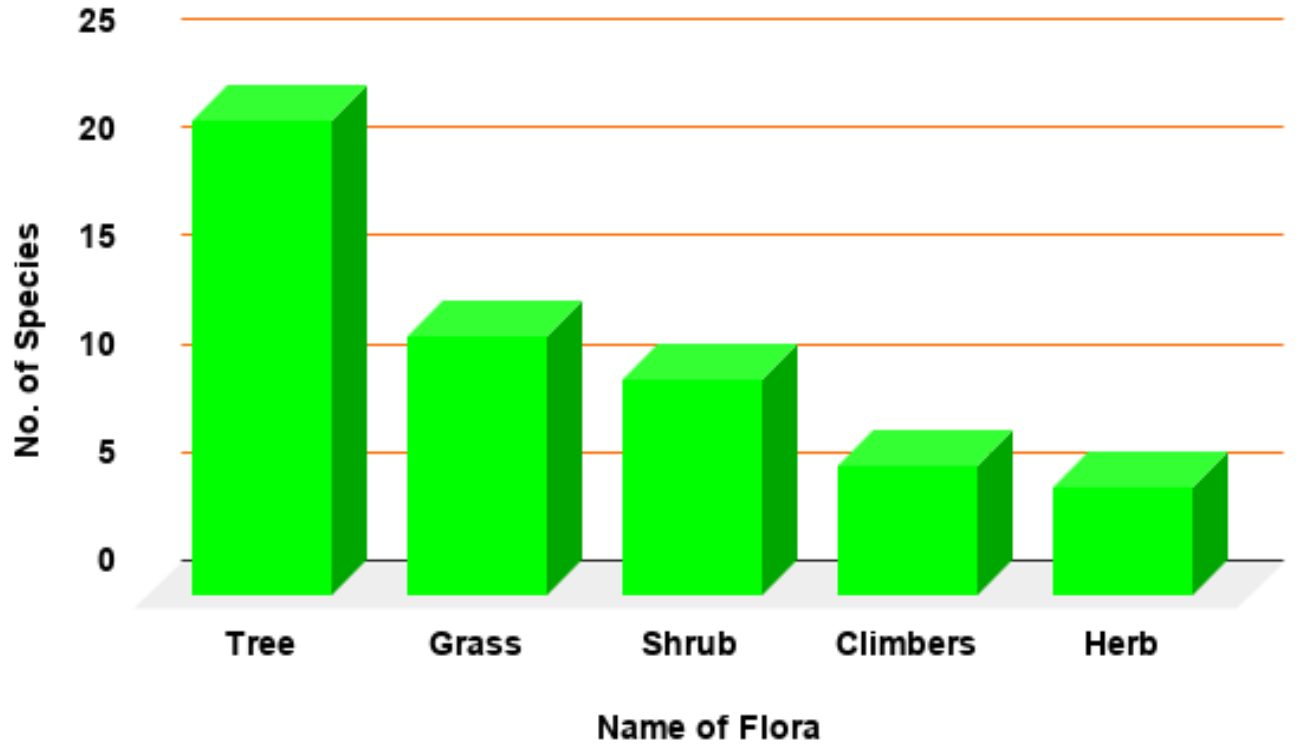

Figure 8: Status of floral diversity of the BNP 


\section{Faunal Diversity}

As a consequence of population and industrial setup, forest is losing its natural habitation, and resulting into the wildlife losing their habitats and food. The results of faunal diversity are shown in Figure 9. The number of bird species existing in the BNP is 29, followed by reptiles (11), mammals (9), and amphibians (4). A significant difference and apparent decline are recorded in the number of wildlife species if compared with previous studies of Sarker and Huq (1985) and Kabir and Ahmed (2005). Loss of birds from the study area is recorded unusually high, with an estimated rate of loss of roughly three-quarters. The reason behind these is military and ground fire activities that extensively disturb wild animals and destroy their habitat and food. Furthermore, visitors walking through the park often disturb wildlife because they are not restricted to footpaths and designated areas (Rahman and Vacik, 2009).

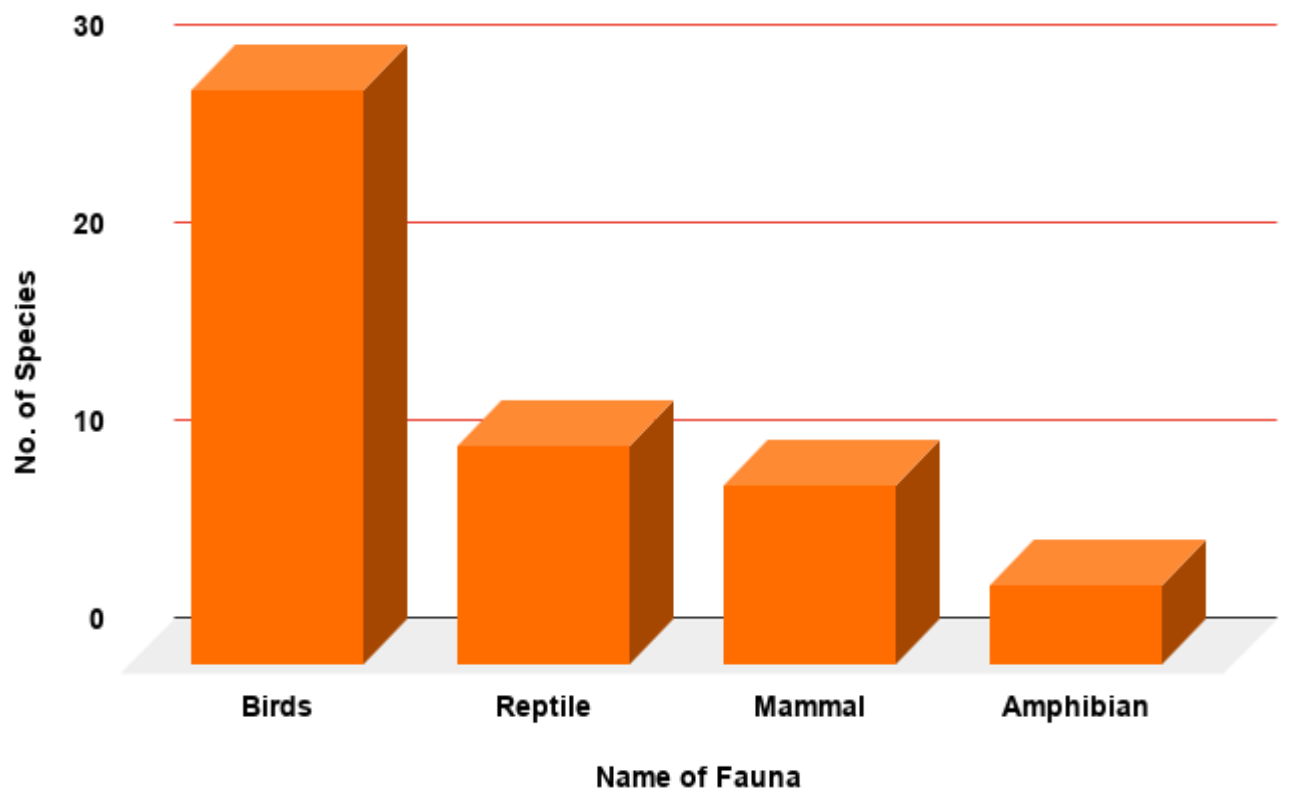

Figure 9: Status of faunal diversity of the BNP

\section{Conclusion}

Sal forest is the only plain land forest in Bangladesh and is important from both national economic and environmental perspectives. This study discovers that the existing Sal forest management practices are inadequate and inefficient to manage the forests sustainably. There is a problem of forest administration too between different line departments. This study has identified the factors responsible for forest degradation and biodiversity loss, which are extensive fuelwood collection for cooking purposes, industrial pressure, forest land encroachment, expansion of agricultural lands, and illicit removal of timber wood. It is confirmed that the number of floral species had declined one-third compared to number of species recorded in previous studies. The faunal diversity has significantly deceased than ever before. It is observed that ground fire, military activities, industrial pollution, population expansion, uncontrolled visitors are responsible for 
biodiversity loss. The future existence of the Sal forest depends on due attention given by political leadership and reduced urbanization.

\section{Acknowledgment}

The authors acknowledge the support provided by the Department of Environmental Science and Resource Management at Mawlana Bhashani Science and Technology University, Tangail. We are grateful to Divisional Forest Office and Range Office of Bhawal National Park (BNP) for their special cooperation during the study. Last but not least, our sincere thanks to all our study respondents for their contribution to this study.

\section{Reference}

Ahsan, M.M., Aziz, N. and Morshed, H.M. (2016). Assessment of Management Effectiveness of Protected Areas of Bangladesh. SRCWP Project. Bangladesh Forest Department, Dhaka.

Akber, M.A. and Shrestha, R.P. (2013). Land-use change and its effect on biodiversity in Chiang Rai province of Thailand. Journal of Land Use Science, 10: 108-128. Doi: http://dx.doi.org/10.1080/1747423X.2013.807315

Alam, M., Furukawa, Y., Sarker, S.K. Ahmed, R. (2008). Sustainability of Sal (Shorea robusta) Forest in Bangladesh: Past, Present and Future Actions. International Forestry Review, 10(1): 29-37. Doi: http://www.bioone.org/doi/full/10.1505/ifor.10.1.29

BFD (Bangladesh Forest Department) (2013). Protected areas of Bangladesh. Ministry of Environment and Forest, Government of Bangladesh, Dhaka. Online: https:// www.bforest.gov.bd/

BFD (Bangladesh Forest Department) (2016). Forest Fact Sheet: National Tree Planting Campaign and Tree Fair 2016; Bangladesh Forest Department: Dhaka, Bangladesh. Online: https:// www.bforest.gov.bd/

Chowdhury, M.S.H. (Ed.) (2014). Forest conservation in protected areas of Bangladesh. World Forests. Doi: http://dx.doi.org/10.1007/978-3-319-08147-2

Chowdhury, M.S.H. and Koike, M. (2010). An overview of the protected area system for forest conservation in Bangladesh. Journal of Forestry Research, 21(1): 111-118. Doi: http://dx.doi.org/10.1007/s11676-010-0019-x

Chowdhury, M.S.H., Koike, M. and Muhammed, N. (2009). Embracing collaborative protected area management for conservation: an analysis of the development of the forest policy of Bangladesh. International Forestry Review, 11(3): 359-374. Doi: http://www.jstor.org/stable/43739810

Chowdhury, R.I. (2013). Attitudes towards co-management: Is Satchari National Park a suitable model for Bhawal National Park? In, Jefferson Fox, M.G. Mustafa, Bryan, R.B., Stephen, M.B. and Laurie, D., Connecting communities and conservation: Co-management initiatives implemented by IPAC in Wetlands and Forests of Bangladesh. USAID/Bangladesh. Online: https://scholarspace.manoa.hawaii.edu/bitstream/10125/30610/2013connectingcommunitie $\underline{\text { s.pdf }}$

DoE (Department of Environment) (2015). The Fifth National Report of Bangladesh to the Convention on Biological Diversity. Department of Environment, Ministry of Environment and Forests, Government of the People's Republic of Bangladesh, Dhaka. 
FAO (2006). Global Forest Resource Assessment. (2005). Progress towards sustainable forest management, FAO, Forestry Paper 147. Rome (Italy): Food and Agriculture Organization of the United Nations (FAO).

FAO Global Forest Resources Assessment (2015). Desk Reference; Food and Agriculture Organization of the United Nations: Rome, Italy.

Ghosh, D.K., Hossain, M.N., Sarker, M.N.S. and Islam, S. (2020). Effects of land-use changes pattern on tree plantation: Evidence from gher land in Bangladesh. International Journal of Agricultural Policy and Research, 8(3): 56-65. Doi: https://doi.org/10.15739/IJAPR.20.007

GOB (Government of Bangladesh) (2006). Participatory Sal coppice Management: Bulletin No. 6. Forestry Sector Project. Forest Department, Dhaka, Bangladesh.

Hasan, E. and Khalid, M.B. (2014). Community's Perception and Involvement in Co-management of Bhawal National Park, Bangladesh. Journal of Natural Sciences Research, 4(3): 2014. Online: www.iiste.org

Hasan, M.K., Rahman, G.M.M., Akter, R. Hemel, S.A.K. and Islam, M.T. (2020). Economic assessment of lemon-based agroforestry systems established in the Madhupur Sal forest area of Bangladesh. Progressive Agriculture, 31(1): 45-55. Online: http://www.banglajol.info/index.php/PA

Hossain, M.N., Rahman, M.M. and Islam, K. (2016). The Vulnerability of Agricultural Production due to Natural Disaster at Mongla Upazila (Sub-district) in Bangladesh. British Journal of Applied Science \& Technology, 16(1): 1-13. Doi: https://doi.org/10.9734/BJAST/2016/26007

Hossain, M.N., Rokanuzzaman, M., Rahman, M. and Bodiuzzaman, M. (2015). Causes of Deforestation and Conservation of Madhupur Sal Forest in the Tangail Region. Journal of Environmental Science and Natural Resources, 6(2): 109-114. Doi: https://doi.org/10.3329/jesnr.v6i2.22105

Hossain, M.N., Saifullah, A.S.M., Bhuiyan, S., Uddin, N. and Rahman, M. (2019). Effects of climate change on rice production at Khulna district, Bangladesh. Environ. Earth Ecol., 3(1): 42-54. Doi: https://doi.org/10.24051/eee/110398

Islam, M.K, Jashimuddin, M. and Hossain, M.N. (2017). Tree Diversity and Management of Village Common Forests in Bandarban. Environ Earth Ecol, 2: 39-51. Doi: https://doi.org/10.24051/eee/76920

Islam, S. and Ma, M. (2018). Geospatial monitoring of land surface temperature effects on vegetation dynamics in the Southeastern Region of Bangladesh from 2001 to 2016. International Journal of Geo-Information, 7(12): $486 . \quad$ Doi: http://dx.doi.org/10.3390/ijgi7120486

Islam, S.S. (2003). State of forest genetic resources conservation and management in Bangladesh. Forest Genetic Resources Working Papers. Forest Resources Division, FAO, Rome, Italy. 28 pp.

Ismail, M. and Mia, M.M.K. (1973). Studies on some deciduous 'Sal' forests of Bangladesh. Ecology of Bangladesh Vegetation, 2: 79-103.

Jahan, I., Paul, E. Mollik, A., Sultana, N. and Roy, K. (2017). Anuran Diversity in Bhawal National Park, Gazipur, Bangladesh. IRCF Reptiles \& Amphibians, 24(1): 36-42.

Kabir, D.S. and Ahmed, A.Z. (2005). Wildlife Biodiversity in Bhawal National Park: Management Techniques and Drawbacks of Wildlife Management and Nature Conservation. Our Nature, 2005(3): 83-90. 
Macura, B., Secco, L. and Pullin, A.S. (2015). What evidence exists on the impact of governance type on the conservation effectiveness of Forest protected areas? Knowledge base and evidence gaps. Environ Evid., 4: 24. Doi: http://dx.doi.org/10.1186/s13750-015-0051-6

Masum, K.M., Islam, M.N., Saha, N., Hasan, M.Z. and Mansor, A. (2015). Assessment of land grabbing from protected forest areas of Bhawal National Park in Bangladesh, Landscape Research, 41(3): 330-343. Doi: http://dx.doi.org/10.1080/01426397.2015.1078456

MoEF and FAO (2007). National Forest and Tree Resources Assessment 2005-2007, Bangladesh; Ministry of Environment and Forests (MoEF) and Food and Agriculture Organization of the United Nations (FAO), Dhaka, Bangladesh.

Mohd, A., Jusoff, K., Sheikh, A.H. and Yaman, A.R. (2008). The Management of Bhawal National Park, Bangladesh by the Local Community for Resource Protection and Ecotourism. Asian Social Science, 4(7): 101-107. Online: www.ccsenet.org/journal.html

Mukul, S.A. (2007). Biodiversity conservation strategies in Bangladesh: The state of protected areas. Tiger paper, 34(3): 28-32.

Mukul, S.A. and Quazi, S.A. (2007). Communities in conservation: Changing protected area management and enhanced conservation in Bangladesh. In: R. N. Leslie (Ed.), The future of forests in Asia and the Pacific: Outlookfor 2020 (pp. 143-159). Chiang Mai, Thailand: Food and Agriculture Organization of the United Nations.

Mukul, S.A., Biswas, S.R. and Rashid, A.Z.M.M. (2018). Biodiversity in Bangladesh. In: Pullaiah, T. (Ed.), Global Biodiversity, Vol. 1: Selected Countries in Asia. Canada: Apple Academic Press, pp. 93-107.

Mukul, S.A., Uddin, M.B., Uddin, M.S., Khan, M.A.S.A. and Marzan, B. (2008). Protected areas of Bangladesh: Current Status and Efficacy for Biodiversity Conservation. Proc. Pakistan Acad. Sci., 45(2): 59-68.

Nishat, A., Huq, S.M.I., Barua, S.P., Reza, A.H.M.A. and Khan, A.S.M. (2002). Bio-ecological Zones of Bangladesh. World Conservation Union, Dhaka, Bangladesh, $141 \mathrm{pp}$.

NSP (2006). Protected Areas of Bangladesh: A visitor's guide. Nishorgo Support Project, Dhaka. $41 \mathrm{pp}$.

Rahman S.S. and Vacik, H. (2015). Identify Appropriate Conservation Strategies for Rural People in Bangladesh. J Biodivers Manage Forestry, 4: 1. Doi: https://doi.org/10.4172/2327$\underline{4417.1000137}$

Rahman, M. and Miah, M.D. (2017). Are protected forests of Bangladesh prepared for the implementation of REDD+? A forest governance analysis from Rema-Kalenga Wildlife Sanctuary. Environments, 4(2): 43. Doi: https://doi.org/10.3390/environments4020043

Rahman, M.M. and Vacik, H. (2009). Can picnic influence floral diversity and vitality of trees in Bhawal National Park of Bangladesh? For. Stud. China, 11(3): 1-10. Doi: https://doi.org/ 10.1007/s11632-009-0000-0

Rahman, M.M., Motiur, M.R., Guogang, Z. and Islam, K.S. (2010). A review of the present threats to tropical moist deciduous Sal (Shorea robusta) forest ecosystem of central Bangladesh. Tropical Conservation Science, 3(1): 90-102. Doi: https://doi.org/10.1177\%2F194008291000300108

Rahman, M.M., Nishat, A. and Vacik, H. (2009). Anthropogenic disturbances and plant diversity of the Madhupur Sal forests (Shorea robusta CF, Gaertn) of Bangladesh. International Journal of Biodiversity Science and Management, 5: 162-173. Doi: http://dx.doi.org/10.1080/17451590903236741

Rashid, A.Z.M.M., Craig, D. and Mukul, S.A. (2016). Shifting Paradigm of Governance in the Natural Resources Management of Bangladesh: A Centralist to Pluralistic Approach in the 
Doi: https://doi.org/10.33002/nr2581.6853.03035

Forest Protected Areas Management. Preprints, 2016: 110-123. Doi: https://doi.org/10.20944/preprints201611.0123.v1).

Salehin, F., Hossain, M.N., Nayeem, A.R. and Hassan, M.R. (2020). The Role of the Constitution in Effective Disaster Management of Bangladesh. Grassroots Journal of Natural Resources, 3(2): 57-69. Doi: https://doi.org/10.33002/nr2581.6853.03025

Sarker, N.M. and Fazlul-Huq, A.K.M. (1985). Country report on national parks, wildlife sanctuaries and game reserves of Bangladesh. Prepared for the 25th Working Session of IUCN's Commission on National Parks and Protected Areas. Corbett National Park, India. $5 \mathrm{p}$.

Sharma, R., Decosse, P., Roy, M., Khan, M. and Mazumder, A. (2006). Co-management of protected areas in South Asia with especial reference to Bangladesh. Dhaka: Partner Report, Nishorgo Support Project (with FD, USAID, and IRG).

Sohel, M.S.I., Mukul, S.A. and Chicharo, L. (2015). A new ecohydrological approach for ecosystem service provisions and sustainable management of aquatic ecosystems in Bangladesh. Ecohydrology \& Hydrobiology, 15: 1-12.

Sunderland, T.C.H., Kibria, M.G., Rahman, S. A. and Imtiaj, A. (2011). Depleting tropical Forest at a landscape scale: finding solutions for Bangladesh. Journal of Biodiversity and Ecological Sciences, 1(1): 53-64. Online: http://www.cifor.org/library/3358/depleting tropical-forest-ata-landscape-scale-finding-solutions-for-bangladesh/. 